First Peoples Child \& Family Review

An Interdisciplinary Journal Honouring the Voices, Perspectives, and Knowledges of First Peoples through Research, Critical Analyses, Stories, Standpoints and Media Reviews

\title{
Aboriginal Youth Gangs: Preventative Approaches
}

\section{Jane P. Preston, Sheila Carr-Stewart and Charlene Northwest}

Volume 4, Number 2, 2009

URI: https://id.erudit.org/iderudit/1069339ar

DOI: https://doi.org/10.7202/1069339ar

See table of contents

Publisher(s)

First Nations Child and Family Caring Society of Canada

ISSN

1708-489X (print)

2293-6610 (digital)

Explore this journal

Cite this article

Preston, J., Carr-Stewart, S. \& Northwest, C. (2009). Aboriginal Youth Gangs: Preventative Approaches. First Peoples Child \& Family Review, 4(2), 152-160. https://doi.org/10.7202/1069339ar

\section{Article abstract}

The purpose of this article is to describe programs and strategies dissuasive of Aboriginal youth gang involvement. Individual approaches target areas such as antisocial behavior, personal challenges, and negative thinking patterns. Family-orientated approaches reaffirm family values as a means to deter youth from gang association. Providing positive opportunities for youth to interact with community role models and to partake in community programs are also dissuasive to the proliferation of Aboriginal youth gangs. Although information herein is intended to tackle Aboriginal youth gang issues, it can also be useful in addressing peripheral social issues within communities, in general.
This document is protected by copyright law. Use of the services of Érudit (including reproduction) is subject to its terms and conditions, which can be viewed online.

https://apropos.erudit.org/en/users/policy-on-use/ 


\title{
INitest Peoples Child \& Samily Review
}

An Interdisciplinary Journal Honoring the Voices, Perspectives and Knowledges of First Peoples through Research, Critical Analyses, Stories, Standpoints and Media Reviews

Volume 4, Number 2, 2009, pp. 152-160

\section{Aboriginal Youth Gangs: Preventative Approaches}

\author{
Jane P. Preston ${ }^{\mathrm{a}}$, Sheila Carr-Stewart ${ }^{\mathrm{b}}$ and Charlene Northwest ${ }^{\mathrm{c}}$
}

\author{
${ }^{a}$ B.Ed., M.Ed., Ph.D. Candidate, graduate student, University of \\ Saskatchewan, Saskatoon, Saskatchewan, Canada. \\ b B.A., M.A., M.Ed., Ph.D., Department Head Educational \\ Administration, University of Saskatchewan, Saskatoon, \\ Saskatchewan, Canada. \\ c B.Comm., Consultant for Samson Cree Nation, Hobbema, \\ Alberta, Canada.
}

\section{Introduction}

Fifteen years ago, Aboriginal youth gangs and their related atrocities were, for the most part, nonexistent. These days, especially across the Prairie Provinces, Aboriginal youth gangs are an increasingly prevalent, highly-profiled phenomenon. The alarming growth rate of Aboriginal youth gangs is particularly apparent within urban centers such as Winnipeg, Regina, Saskatoon, and Edmonton (Bernhardt, 2006). As Chettleburgh (2003) highlighted, approximately $96 \%$ of youth gang members within Saskatchewan and 58\% of youth gang members in Manitoba and Alberta are of Aboriginal decent. On a per capital basis, Saskatchewan has the highest concentration of youth gang membership in all of Canada, with 1.34 gang members per 1,000 people. Over $90 \%$ of Aboriginal gang inmates are imprisoned in penitentiaries across the Prairies (Chettleburgh, 2003). As Cuthand (2008b) stated,

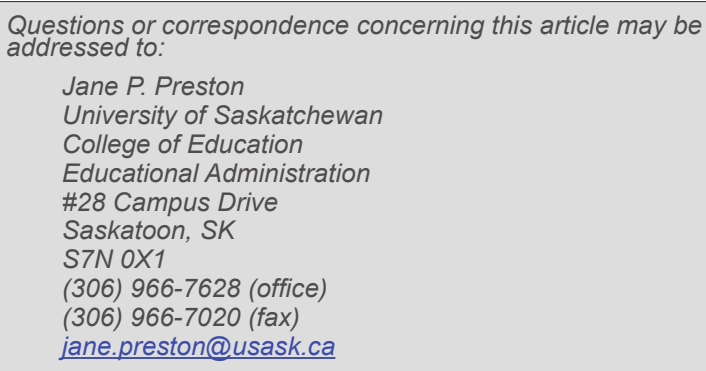

\begin{abstract}
The purpose of this article is to describe programs and strategies dissuasive of Aboriginal youth gang involvement. Individual approaches target areas such as antisocial behavior, personal challenges, and negative thinking patterns. Family-orientated approaches reaffirm family values as a means to deter youth from gang association. Providing positive opportunities for youth to interact with community role models and to partake in community programs are also dissuasive to the proliferation of Aboriginal youth gangs. Although information herein is intended to tackle Aboriginal youth gang issues, it can also be useful in addressing peripheral social issues within communities, in general.
\end{abstract}

"Jails in Saskatchewan are nothing but crime factories that are run by gangs" (p. A13).

The reasons for and consequences of Aboriginal gangs are linked to the social realities endured by many Aboriginal peoples. For example, over half (52\%) of Aboriginal children live in poverty, as compared to $23 \%$ of non-Aboriginal children (Anderson, 2003). Suicide is five to six times more prevalent among Aboriginal youth, as compared to non-Aboriginal youth (Anderson, 2003). Many Aboriginal youth are at risk of being recruited by gangs due to additional factors including (but are not limited to) lack of employment opportunities, institutional racism and discrimination, and a sense of hopeless (Federation of Saskatchewan Indian Nations, 2003). The National Chief of Congress of Aboriginal Peoples, Kevin Daniels, stated that the expansion of Aboriginal youth gangs has led to an increase in gang-related deaths, alcohol and drug abuse, poverty and homelessness among Aboriginal youth ("Interview with National Chief," 2009). Moreover, these gang-related issues, particularly within Alberta and Saskatchewan, will likely exacerbate due to increasing demand for illicit drugs within the oil-rich, affluent Prairie Provinces (Adam, 2009; Alberta Alcohol and Drug Abuse Commission, 2005; Stolte, 2008; 
Friesen \& O’Neill, 2008). Chief Lawrence Joseph of the Federation of Saskatchewan Indian Nations (Cherry, 2005) warned that timing is vitally important because if Aboriginal youth gang issues are left ignored, in the near future, the problem will exponentially worsen.

The literature pertaining to youth gangs describes a myriad of ways to reduce the criminal activities and devastation caused by gangs. Remedies range from persuading parents to decrease the amount of violent television children watch to increasing police presence in identifiable gang territory. However, expanding police presence to control gang activity is only one way to address Aboriginal youth gang issues. Polischuk (2009) believed a more effective way to deal with Aboriginal youth gangs is to focus upon preventative programs and strategies, thereby pre-empting issues undergirding youth gang proliferation.

Throughout this paper, we extrapolate the idea that problems associated with the proliferation of Aboriginal youth gangs need to be addressed through enhancing individual, family, and community wellness. Within each of these areas, we provide an overview of strategies and established programs, which target Aboriginal youth gang issues. Although specific approaches are delineated within the categories of individual, family, and community, we recognize these strategies and programs are multifaceted and can overlap categories. Another important point to consider is that while the information presented within this article can be directly applied to preventing Aboriginal youth gang escalation, these preventative approaches can also be adapted to address peripheral social issues within communities, in general.

\section{Individual Wellbeing}

A growing number of researchers, law enforcement agents, and other stakeholders actively engaged in youth gang reduction are demanding a paradigm shift regarding the approaches used to curtail youth gang activity. This new mindset diverts attention from tactics of suppression and incarceration as a core means to control youth gangs toward promoting the amelioration of preventative programs and policies that foster positive identities for individuals prone to youth gang involvement. Preventative programs targeted at Aboriginal youth gang involvement logically infer that strategies focusing on individual wellness need be put in place within communities before youth gangs become an issue; thus, the implementation of such programs need to be established early - as early as during the infancy stages of child development.

Gatti, Tremblay, Vitaro, and McDuff, (2005) indicated youth who are raised in challenging childhoods environments are more prone to join gangs and stay in gangs for a longer duration of time, as compared to children who experience more nurturing childhoods. One way to ensure that an equitable start to life is bestowed upon young children is through the provision of quality childcare and early intervention programs (OECD Directorate of Education, 2004). During the past ten years, a spate of early childhood development programs has surfaced across Canada (see Friendly, Beach, Ferns, \& Turiano, 2007), and, fortunately, some of this attention has been funneled toward enhancing Aboriginal childcare programs. Preston (2008a) identified a variety of federally-funded Aboriginal early intervention programs including: Aboriginal Head Start in Urban and Northern Communities, First Nations and Inuit Child Care Initiative, First Nations National Child Benefit Reinvestment, Brighter Futures, and Maternal Child Health Program. These programs are primarily intended for children from newborn to age five and are developed through the incorporation of: (a) a local Aboriginal curriculum; (b) Aboriginal self-governance; and (c) Indigenous culture and language. Quality Aboriginal childcare programs can positively influence the spiritual, emotional, physical, and intellectual development of young children (Greenwood, 2005). Such a salubrious approach to child wellness helps to deter the onset youth gang proliferation within a community.

Another approach dissuasive to Aboriginal youth gang proliferation focuses on strengthening the positive self-concept and culture identity of young people. As explained by Dukes, Martinez, and Stein (1997), many youth who want to be or who are affiliated with youth gangs have a negative self-image. "Gang members [tend] to be persons with identity problems - who [do] not feel good about themselves, [have] less confidence in their academic abilities, [have] lower feelings of purpose in life, and [have] weak attachments to their ethic group" (p. 152). Hence, preventative approaches need to target such things as: anti-social behavior, personal challenges, negative thinking patterns, and negative lifestyles. Brendtro and Larson (2004) argued that although many at-risk youth have endured traumatic experiences, young individuals are generally resilient and can lead productive and fulfilling lives, provided they are surrounded by supportive leaders who supply intrinsically meaningful ways to develop personal strength and positive values. Deterring individuals from becoming involved with youth gangs is synonymous to celebrating personal abilities, reaffirming positive personal goals, and restoring a sense of hope.

In an effort to nurture the emotional and spiritual strength of Aboriginal youth, constructive leadership and affirmative peer pressure must be readily accessible for individuals who may be attracted to the false lure of gang lifestyles. Specifically, Aboriginal youth need to be provided with more opportunity to develop self- 
competency in areas such as education, Indigenous language, vocational training, culture knowledge, and social demeanor. By doing so, Aboriginal youth will feel more in control of their lives, life choices will become more abundant, and the development and sustainability of a healthy lifestyle will be more readily secured (Brendtro, Brokenleg, \& Van Brockern, 2002).

\section{Application of Programs for Individual Wellbeing}

One program that focuses on the constructive and enabling abilities of at-risk children is called PALS. PALS stands for Positive role models, Academic tutoring, Leisure and physical activity, and Social development (Schneider, 2007). An established PALS program (located in St. Mary's University, Nova Scotia) provides a weekly bus service to children from ages 5 to 12 and offers an abundance of youth-related activities. The program aims to address five key areas vital to the positive development of children: (a) education/academic development; (b) life and social skills/ behavioral development; (c) physical activity and health development; (d) mentors and positive role models; and (e) effective parenting and a nurturing social environment (Schneider, 2007).

The PALS program, itself, can be implemented in communities with gang-related issues, or a modification of the program could be delivered through various versions of local after-school programs. As indicated by Maxson, Whitlock, and Klein (1998), individuals who are more at risk of joining youth gangs are young people who have high levels of unstructured and unsupervised social time with other youth. Chettleburgh (2007) identified after-school time as empty time. He explained that the time between 3:00 p.m. and 6:00 p.m. is one of the riskiest times for adolescents to become victimized and/ or running afoul of the law. Specifically, during this time, there is significant merit to keeping children busy, rather than, for example, letting them hang out at a mall with unsupervised youth. Quality, after-school programs have been shown to be an effective buffer against delinquency, as they provide alternative, fun activities for children (Chettleburgh, 2007; Lee, 2001). Moreover, constructive, organized activities can benefit children by improving their social skills, health, confidence, grades, and positive peer networking. Examples of after-school programs include: sport leagues, computer clubs, horseback riding, tutoring time, arts and crafts programs, cooking clubs, traditional dance clubs, employment preparation training, language instruction, music clubs, and community revitalization programs. Once an after-school program is in place, it is also important that organizers consider continuing the program throughout the months of July and August, when school is not in session. By doing so, the unstructured time of the summer holidays can continue to be filled with activities that foster the social development and wellbeing of youth, while simultaneously deterring children from gang-related activities.

A common characteristic of many individuals at risk of joining youth gangs is they possess inherent entrepreneurial skills; hence, the financial advantage of gang life is compelling to them (Chettleburgh, 2007; Stolte, 2008). To more positively channel the entrepreneurial potential of youth, employment opportunities and self-employment training programs need to be available to adolescents during school time and as an extra-curricular option. An example of such fecund endeavors is actualized within Osakayak High School in Saskatoon. This school sponsored an entrepreneurial project as part of its Aboriginal Youth Education Program (AYEP). Through the structure of the program, the students created and sustained a fairly lucrative business by designing Aboriginal t-shirts (Loleit, 2007).

There are a variety of other programs dedicated to utilizing the vast talents and entrepreneurial skills of young individuals. Another after-school program is called Junior Achievement Canada, which is dedicated to educating young people about the expertise required to create and sustain their own business. Junior Achievement Canada provides young children with leadership, entrepreneurial, and workforce readiness skills (Junior Achievement, 2008). Job placement services and apprenticeship programs, such as the Aboriginal Apprenticeship Program (Aboriginal Futures, n. d.) are additional ways to prepare young adolescence to enter the workforce. Such services provide youth with experience in the trades, which are presently in very high demand, especially within the Prairie Provinces (Preston, 2008b). Summer youth employment programs sponsored within local communities also provide young individuals with employment experience and economic gain.

In sum, preventative programs that focus on the individual's wellbeing reaffirm the budding potential of young Aboriginal individuals. Ascertaining the healthy development of youth begins at birth and is supported through the provision of quality Aboriginal childcare and early intervention programs. By reestablishing constructive goals, by rechanneling talents and abilities, by redirecting a sense of hope, and by focusing entrepreneurial skills on positive business endeavors, individuals lured toward youth gang involvement are more likely to focus on more personally rewarding dimensions of life.

\section{Family Wellness}

Parents, spouses, siblings, grandparents, Elders, aunts, uncles, cousins, and the extended family are an integrated 
part of the growth and development of an Aboriginal child. Personal networking among Aboriginal family and community members often results in intimate social bonding, thereby supporting the survival and prosperity of each family, and, in turn, of the entire community. The National Indian Brotherhood \& Assembly of First Nations (1989) stated, “An Aboriginal child's sense of security and belonging is based on cooperation and harmony within the extended family" (p. 9). In this light, family wellness is an extremely important buffer against gang proliferation.

Research indicates that membership within gangs is often prognosticated by a difficult family environment. Franzese, Covey, and Menard (2006) proposed, "The most important influence on the decisions to join gangs is whether parents, siblings, and friends are or have been gang members" (p. 205). Sgt. Olson of RCMP's Integrated Gang Intelligence Unit agreed that youth gang affiliation is sometimes groomed by parental influences. Police officers witness gang-member parents dress their newborn to five-year-old children with gang regalia; other young children are taught by their parents to imitate specialized hand gestures utilized by youth gangs (Bernhardt, 2006; "Girls and Gangs," 2007). With that stated, in order to prevent children from being involved with gangs, parents need to do more than simply not affiliate with gangs. Parents need to incorporate positive child rearing propensities into their home life, because, as Hill, Howell, Hawkins, and Battin-Pearson (1999) stipulated, children whose parents lack proper child management skills are more prone to gang membership. In addition to parents, siblings also have a powerful influence on young children and their future choice of whether or not to be involved with gangs. Children whose brothers and sisters display antisocial behaviors and/or associate with gang members experience higher risks of joining gangs (Hill et. al., 1999). Such findings conclude that preventative youth gang efforts need to include the entire family and restructure the maladaptive values and beliefs that may be portrayed within a family unit.

\section{Application of Programs for Family Wellness}

There are a variety of programs that focus on family wellness. FAST (Families and Schools Together) Canada is a program that has been implemented in more than 100 schools across the country. The program is used to strengthen the family unit by addressing parentchild bonding via three main components: (a) building a three-way relationship between parents, children, and school; (b) addressing personal values, personal accountability, and family management; (c) empowering parents to become the primary protectors of their children (Wisconsin Center for Education Research, 2007). A

(C) Jane P. Preston, Sheila Carr-Stewart and Charlene Northwest participating family is invited to the school one evening a week for eight to 14 weeks. In an effort to address the cultural needs of Aboriginal peoples, FAST Canada has been adapted into an affiliated program called Aboriginal FAST (Family Services Canada, 2009).

Fortifying family wellness may mean advising parents how to constructively deal with aggression in children. The Incredible Years: Parent, Teachers, and Children Training Series is a prevention and intervention program targeting children from ages four to eight who are highly aggressive, disobedient, hyperactive, and inattentive (The Incredible Years, 2008). This curriculabased program provides a variety of training modules created for parents, teachers, and children. For this program, off-site leader training is available, and, after completion of the course, the trained individual comes home to deliver the information to community members. As well, an outside instructor can travel to a community and present course information. The Incredible Years program has been recognized by the U.S. Department of Justice as an exemplary program for effectively reducing violence and delinquency in children (Webster-Stratton, 2000). In addition to the United States, The Incredible Years is currently active throughout Canada and the United Kingdom. A strong point of the programs is that it can be delivered in the community by trained local community leaders.

Another program designed specifically for strengthening the family unit is called Functional Family Therapy (FFT). This program targets youth aged 11 to 18 , who are either at risk or are presenting delinquent and violent behavior, substance use, and various behavior disorders (Alexander et al., 1998). The program has a flexible implementation process and can be delivered to clients in their homes, within a clinic, at school, through community-based programs, and within various institutional settings (Alexander et al., 1998). Functional Family Therapy is an effective intervention strategy for recently released high-risk offenders (Sexton \& Alexander, 2000). Alexander et al. (1998) explained that the duration of the program is approximately three months, consisting of 12 , one-hour sessions. Both trained therapists and court workers who received Functional Family Therapy training deliver the program. A review of the program demonstrated vast cost benefits directly related to lowering recidivism rates. Within the United States, the programs has saved from $\$ 7.69$ to $\$ 13.25$ per dollar invested (Washington State Institute for Public Policy, 2004). Although Functional Family Therapy is an American program, Violato, Genius, \& OddonePaolucci (2008), representing Correctional Services Canada, recognized Family Functional Therapy as one of the most promising approaches to family therapy for young offenders within Canada. Currently, there is not an

C Jane P.Preston, Sheila Carr-Stewart and Charlene Northwest 
Aboriginal-based equivalent of this program located in Canada.

The Aboriginal Youth \& Family Well Being and Education Society (n.d.) is a non-profit agency focused on promoting the success of young Aboriginals through the provision of positive learning excursions, which are lead by Aboriginal volunteers. In order to improve the conditions faced by Aboriginal youth and their families, this organization provides a number of venues and ideas for Aboriginal child and family wellness, including cultural camps, cultural ceremonies, and traditional pursuits such as hunting and trapping.

Promoting the strength of the family unit is formidable force against the proliferation of youth gangs. The Royal Commission on Aboriginal Peoples (1996) explained, "... healthy families are the foundation of strong and healthy communities" (Vol. 3, "Gathering Strength", para. 27). Preventive programs such as FAST, The Incredible Years, and Functional Family Therapy and associations such as The Aboriginal Youth \& Family Well Being and Education Society empower parents by enhancing parent-child relationships. Through family participation in Indigenous cultural ceremonies, Aboriginal family values are recognized and celebrated. These family-centered activities support the perpetuation and wellbeing of Aboriginal families and are a protective force against Aboriginal youth gangs.

\section{Community Wellness}

Throughout the decades, Aboriginal peoples have long endured a host of unfair social, economic, and geographical barriers, all of which have had traumatic, detrimental effects upon them, their families, and their culture. As described earlier, these formidable obstacles have created a society that provides unequal health and welfare opportunities for Aboriginal peoples. As a result, some young Aboriginal people have lost their cultural roots and no longer see themselves as an important part of their community. In relation to youth gangs, studies indicate that gang members are often young people who feel disenfranchised from their community, culture, and family (Federation of Saskatchewan Indian Nations, 2003).

Fred (2000) explained, "Native people are being encouraged to get in touch with their culture and to use it for the betterment of their people" (p. 301). The Federation of Saskatchewan Indian Nations (2003) believed that government policies must support Aboriginal communities that supply alternatives to the criminal justice system for youth. Thus, through the teaching of Aboriginal traditions and culture, some Aboriginal communities deliver prevention and intervention programs that are focused on the healing of gang members and the restoration of Aboriginal communities. For example, Ellerby and Ellerby (1998) studied the role of Elders and traditional healing as an effective treatment for Aboriginal criminal offenders. In their research, they found the non-judgmental, spiritual attitudes of Elders to be a core element of their therapeutic approach to healing Aboriginal peoples. Elders believed there needs to be a revitalization of the Aboriginal ceremonies and teachings within local communities, and these fundamental teachings are a necessary and effective way to treat Aboriginal offenders, dissuade at-risk youth from joining gangs, and re-constitute a healthy lifestyle into the community. Elder wisdom is vital to the overall wellness and healing process of Aboriginal peoples and their communities (Ellerby \& Ellerby, 1998).

In 2000, Ovide Mercredi authored a document for Correctional Service Canada that focused on Aboriginal gang members in the federal corrections system. An important recommendation within this report supported the idea that Aboriginal community members, especially Elders, need to provide Aboriginal youth with a sense of culture, pride, and identity. For example, traditional Aboriginal dance has been identified by the Beardy Okemasis First Nations (Saskatchewan) as a playing a vital role in keeping young people in touch with First Nations community values (Hughes, 2007). Many Aboriginal gang members want to change, but lack the tools and knowledge to stabilize and better themselves (Dolha, 2003). In relation to this point, Phillips (as cited in Dolha, 2003) stated that many Aboriginal gang members respect their Elders and their traditional culture. The reverence that many gang members have for their traditions creates a window of opportunity or a sense of direction such that gang members can re-evaluate their ways and regain personal focus rooted within Aboriginal culture.

In addition to the assistance of Elders', community members also have vast potential to help address gang problems. Unfortunately, due to fears of retaliation, people sometimes remain silent and choose to do nothing about the gang-related problems apparent within their community (Cuthand, 2008a). Saccone (2005) indicated that when community members do not unite, members try to individually protect themselves by putting locks and bars on the doors and windows of their homes. Such actions symbolize the rampant fear within the community, fear that further empowers gangs and their followers. Thus, community members need to assemble and address the gang-related problems of their community. In an effort to expose and resolve local gang issues, community members also need to be informed about professionals and organizations who/that they can turn to for confidential assistance. Most often the community members know who the drug dealers are and the location 
of houses affiliated with gang members. Community members have valuable knowledge and, thereby, can offer suggestions to help specific individuals. The assistance of community members can take on a variety of additional forms. Community members can participate in community beautification initiatives such as a graffiti wipe campaign (Saccone, 2005). In some cases, community members have enforced curfews to deter gang members from congregating during specific times and locations (Delaney, 2006). Some Aboriginal communities have utilized traditional methods, such as banishment of gang leaders from their communities. In such a case, a band council can pass a resolution to banish a person or persons from a reserve (Cuthand, 2008a).

Since the health and wellbeing of Aboriginal people flows largely from the health and social make-up of the community (Health Canada, 2005), strengthening the community's protective factors is a key aspect in dissuading gang involvement. The community's protective factors include: providing opportunities for youth to build positive relationships with mentors, providing an abundance of role models/positive social peers, supporting family and community service programs (Public Safety Canada, 2007), and providing opportunities for Aboriginal youth to connect with their Indigenous language and culture.

\section{Application of Programs for Community Wellness}

In 2005, the Hobbema Canadian Mounted Police (Alberta) initiated a community crime reduction initiative to disrupt gang activity, illicit drug use, and violence within the Hobbema area. This initiative, called the First Nations Hobbema Community Cadet Corps Program, tailored its activities to meet the needs and concerns of its youth by placing a strong emphasis on Aboriginal culture, language, education, sports, and a healthy lifestyle (Hobbema Community Cadet Corp, 2008). The program provided mentors who taught young cadets to concentrate on positive attitudes, abilities, and achievements, rather than focusing on negative obstacles that hinder success (Hobbema Community Cadet Corp, 2008). Interestingly, the focus of the Hobbema Community Cadet Corp is similar to the focus of the PALS program, as described previously. Both programs are centered on accentuating the positive skills and talents possessed by every individual.

Part of a community effort to suppress the destructive power of gangs is to try to reduce the duration of time that an individual belongs to a gang. For most young people, gang membership is a brief phase of their life, as about two-thirds of youth gang members leave the gang within one year (Hill, Lui, Hawkins, 2001;
Thornberry, 1998). This information supports the idea that the community must provide appropriate services and facilities for gang members once they have formally cut ties to a gang. Such services include alcohol and drug treatment, employment opportunities, and educational opportunities (Public Safety Canada, 2007). Furthermore, research indicated that the most common reason for leaving a gang is personal maturity (Campbell, 1991; Franzese et al., 2006). As teenage gang members enter young adulthood, they are more prone to experience adult responsibilities including parenthood, marriage, and steady employment (Campbell, 1991; Franzese et al., 2006). Strong attachment to and involvement with family, school, community, cultural institutions, and employment opportunities help reduce gang proliferation.

An integral part of the community is its school, and, as such, the school is an ideal place to deliver gangawareness programs and various gang-related forums. As referred to earlier, Osakayak High School hosted a Gang Awareness Day. A youth group participated in the planning of the day, which included wrap-up activities such as talking circles used to debrief and de-escalate fears and uncertainties resulting from the day's information (Federation of Saskatchewan Indian Nations, 2003). It is important to remember that if teachers are asked to deliver gang-awareness programs, providing professional development for them in this area is essential.

Another program called GREAT (Gang Resistance Education and Training) is a similar school-based program as Osakayak High School delivered; however, GREAT is taught by trained law enforcement personnel. GREAT is directed at middle school students and provides them with the personal and social tools needed to resist the lure and trap of gangs (Esbensen, 2000). This program, delivered in nine, one-hour lessons not only deters youth from joining gangs, but assists in developing positive relationships with police officers. On this topic Cuthand (2008a) explained:

$$
\begin{aligned}
& \text { Rightly or wrongly, our people have looked upon } \\
& \text { police forces as outside agencies and contact with } \\
& \text { them has generally been negative. Now, we need to } \\
& \text { work with the RCMP and city policy forces to put } \\
& \text { an end to the reign of [gang] terror. (p. A11) }
\end{aligned}
$$

Undeniably, positive partnerships need to be renewed and sustained with law enforcement agencies in an effort to reduce the criminalization of at-risk youth.

Although Chettleburgh (2007) believed that healthy police-community partnerships need to be a focus within the community, he also indicated police need to suppress top gang members by heavily prosecuting the worst $20 \%$ of offenders. These top offenders include gang leaders and core members who are responsible for most of the 


\section{Aboriginal Youth Gangs: Preventative Approaches}

crime. Often the incarceration of marginal gang members further trains youth to become hardened, influential gang members when released from jail, perpetuating the cycle of gang violence (Dolha, 2003). The Federation of Saskatchewan Indian Nations (2003) stated, "Young offender facilities, correctional centers and federal institutions are breeding ground for gang recruitment" (p. 3). Therefore, putting non-gang Aboriginal youth in correctional facilities with hardened gang members often predispositions them for a future life of gang involvement. In response to this point, the Federation of Saskatchewan Indian Nations has called for a moratorium on any increase in beds at young offender facilities (Warick, 2003).

In sum, addressing gang-related challenges is a responsibility that needs to be assumed by all community members living in a neighborhood tormented with youth gangs and related gang violence. Coordinating the community's participation to deter the proliferation of local gangs means that criminal justice systems, community-based agencies, and local grassroots organizations must develop a variety of gang-deterrent policies and programs. In association with the examples highlighted previously, additional examples of community-focused services might include: referring fringe gang members to youth services, sponsoring youth-focused activities within the community, providing community members with professional contacts for gang crisis intervention, advocating safe zones around schools, and providing remedial educational services, job orientation opportunities, job placement and mentoring for at-risk gang members (Spergel et al., 1994). In an effort to support gang-reduction activities, local leadership must be recruited and provided with necessary training. Moreover, in order for communities to activate local leadership and promote community services, funding from local, provincial, and national organizations needs to become readily available. By doing so, communities will be empowered with adequate personal, social, and infrastructural resources to target at gang reduction.

\section{Closing Thoughts}

Across Western Canada, Aboriginal youth gangs have witnessed unprecedented growth, and, as such, there is an urgent need to curtail further proliferation of this phenomenon. To prevent the degradation and carnage associated with gang-related activities, it is paramount that Aboriginal leaders, Elders, and community members provide the mentorship and counseling needed to deter youth from becoming affiliated with gang lifestyles. As mentioned previously, to accomplish these objectives, communities need support from local, provincial, and federal governments. With financial assistance secured, preventative strategies can be directed at strengthening the positive spirit of at-risk youth, enhancing relationship between parents and troubled children, and re-connecting Aboriginal youth to their culture, language, and community. In return, such efforts fortify the health of Aboriginal peoples and the longevity of Indigenous traditions.

Aboriginal tradition promulgates the idea that there exists a delicate interdependence between the individual, the family, the community, and the spiritual order of the universe (Brant-Castellano, 2002). Because of this interrelatedness, harmony or disharmony in any of these four areas has a rippling effect within every other area. Such spiritual insight dictates that a multi-dimensional approach is required to effectively deal with Aboriginal youth gangs. Such spiritual insight also supports the notion that in order to curtail the proliferation of Aboriginal youth gangs, a united effort must be extended from individuals, families, local communities, and local and national leaders throughout Canada.

\section{References}

Aboriginal Futures. (n.d.). Alberta Aboriginal Apprenticeship Program. Retrieved January 9, 2009, from http://www. aboriginalfutures.com/alberta.html.

Aboriginal Youth \& Family Well Being and Education Society. (n.d.). About us. Retrieved January 19, 2009, from http:// www.aboriginalyouth.ca/AboutUs.aspx.

Adam, B. A. (2009, July 9). Rise in crack use fuels crime in city. The StarPhoenix, p. A1.

Alberta Alcohol and Drug Abuse Commission. (2005). Illicit drug use in Alberta. Edmonton, ON: Author.

Alexander, J., Barton, C., Gordon, D., Grotpeter, J., Hansson, K., Harrison, R., et al. (1998). Functional Family Therapy: Blueprints for violence prevention, Book Three. Boulder, CO: Center for the Study and Prevention of Violence, University of Colorado.

Anderson, J. (2003, March). Aboriginal children in poverty in urban communities: Social exclusion and growing racialization of poverty in Canada. Presentation to Subcommittee on Children and Youth at Risk of the Standing Committee on Human Resources Development and the Status of Persons with Disabilities. Ottawa, ON: Retrieved July 20, 2009, from http://www.ccsd.ca/pr/2003/aboriginal.htm.

Bernhardt, D. (2006). Street gangs recruit in schools, educators warmed. The StarPhoenix, p. A3.

Brant-Castellano, M. (2002). Aboriginal family trends: Extended families, nuclear families, families of the heart. The Vanier Institute of the Family. Retrieved February 19, 2009, from http://www.vifamily.ca/library/cft/aboriginal. $\underline{\mathrm{html} \text { \#Conclusion. }}$ 
Brendtro, L., Brokenleg, M., \& Van Brokern, S. (2002). Reclaiming youth at risk: Our hope for our future. Bloomington, IN: Solution Tree.

Brendtro, L., \& Larson, S. (2004). The resilience code: Finding greatness in youth. Reclaiming Children and Youth, 12(4), 194-200.

Caledon Institute of Social Policy. (2002). Families and School Together Canada. Retrieved January 18, 2009, from http:// www.familyservicecanada.org/ files/fast/fast caledon e. pdf.

Campbell, A. (1991). Girl in the gang ( $2^{\text {nd }}$ ed.). Cambridge, MA: Basil Blackwell.

Cherry, T. (2005, March 16). FSIN says it tried to warn police about gang activity. Leader Post, p. A1.

Chettleburgh, M. (2003). Results of the 2002 Canadian policy survey on youth gangs. Ottawa, ON: Public Safety Canada

Chettleburgh, M. (2007). Youth thugs: Inside the dangerous world of Canadian street gangs. Toronto, ON: Harper Collins.

Chettleburgh, M. (2008, June 7). The gangs to fear. National Post, p. A21.

Cuthand, D. (2008a, May 2). Act together to rid community of gang menace. The StarPhoenix, p. A11.

Cuthand, D. (2008b, October 3). Cramming jails proven failure at fighting crime. The StarPhoenix, p. A13.

Delaney, T. (2006). American street gangs. Upper Saddle River, NJ: Pearson Prentice Hall.

Dolha, L. (2003). Aboriginal gangs in Prairie Provinces in "crisis proportions." First Nations Drum, Fall Issue, pp. 1-3.

Dukes, R., Martinez, R., \& Stein, J. (1997). Precursors and consequences of membership in youth gangs. Youth \& Society, 29(2), 139-166.

Ellerby, L. A., \& Ellerby, J. H. (1998). Understanding and evaluating the role of Elders and traditional healing in sex offender treatment for Aboriginal offenders. Ottawa, ON: Aboriginal Corrections Policy Unit.

Esbensen, F. (2000, September). Preventing adolescent gang involvement. Juvenile Justice Bulletin, Washington, DC: Office of Juvenile Justice and Delinquency Prevention Care. Retrieved January 21, 2009, from http://www.ncjrs. gov/html/ojidp/2000 9 2/contents.html.

Family Services Canada. (2009). Aboriginal FAST. Retrieved July 20, 2009, from http://www.familyservicecanada.org/ fst/Aboriginal_FST.html.

Federation of Saskatchewan Indian Nations. (2003). Alternatives to non-violence report: Aboriginal youth gangs exploration: A community development process. Saskatoon, SK: Author.

Franzese, R. J., Covey, H. C., \& Menard, S. (2006). Youth gangs ( ${ }^{\text {rd }}$ ed.). Springfield, IL: Charles C. Thomas.

Fred, R. (2000). Foreword to "resistance and renewal." In R. M. Mann (Ed.), Juvenile crime and delinquency: A turn of the century reader (pp. 293-302). Toronto, ON: Canadian

() Jane P. Preston, Sheila Carr-Stewart and Charlene Northwest
Scholastic Press.

Friendly, M., Beach, J., Ferns, C., \& Turiano, M. (2007). Early childhood education and care in Canada 2006 ( $7^{\text {th }}$ ed.). Toronto, ON: Children's Resource and Research Unit.

Friesen, J., \& O’Neill, K. (2008, May 9). Armed posses spreading violence across the Prairie communities. The Globe and Mail, p. A16.

Gatti, U., Tremblay, R. E., Vitaro, F., \& McDuff, P. (2005). Youth gangs, delinquency and drug use: A test of the selection, facilitation, and enhancement hypotheses. Journal of Child Psychology and Psychiatry, 46(11), 1178-1190.

Girls and gangs. (2007, October 21). Winnipeg Free Press, p. A1.

Greenwood, M. (2005, February). Where to from here? Building a First Nations early childhood strategy. The Assembly of First Nations, Health Secretariat. Retrieved January 3, 2009, from http://www.acc-society.bc.ca/files new/pdf documents/AFN\%20ECD\%20Strategy2\%20final.pdf.

Health Canada. (2005). First Nations, Inuit, and Aboriginal health: Alcohol, drugs \& solvent. Retrieved January 7 , 2009, from http://www.hc-sc.gc.ca/fniah-spnia/substan/ads/ index-eng.phd.

Hill, K. G., Howell, J. C., Hawkins, D., \& Battin-Pearson, C. (1999). Childhood risk factors for adolescent gang membership: Results from the Seattle social development project. Journal of Research in Crime and Delinquency, 36(3), 300-322.

Hill, K. G., Lui, C., \& Hawkins, J. D. (2001, December). Early precursors of gang membership: A study of Seattle youth. Juvenile Justice Bulletin, U. S. Department of Justice. Retrieved January 8, 2009, from http://www.ncjrs.gov/ pdffiles1/ojjdp/190106.pdf.

Hobbema Community Cadet Corp. (2008). Retrieved January 8 , 2009, from http://www.hobbemacadets.net/whoweare.htm

Hughes, L. (2007, Spring). The dance will lead. Prairies North: Saskatchewan's Magazine for Good Prairie Living, pp. 54-63.

The Incredible Years. (2008). About the Incredible Years Program. Retrieved January 18, 2009, from http://www. incredibleyears.com/.

Interview with National Chief Kevin Daniels. (2009, Spring). The Forgotten People. Retrieved July 20, 2009, from http:// www.abo-peoples.org/media/people.pdf.

Junior Achievement. (2008). Retrieved January 19, 2009, from http://www.jacan.org/Lee, S. (2001). Academic effects of after-school programs. Champaign, IL: ERIC

Lee, S. (2001). Academic effects of after-school programs. Champaign, IL: Clearinghouse on Elementary and Early Childhood Education. (ERIC Document Reproduction Service No. ED458010).

Loleit, S. (2007, February 27). AYEP links Aboriginal students to business community. The StarPhoenix, p. B4.

Maxson, C., Whitlock, M., \& Klein, M. (1998). Vulnerability to 


\section{Aboriginal Youth Gangs: Preventative Approaches}

street gang membership: Implications for practice. Social Justice Review, 72(1), 70-79.

Mercredi, O. W. (2000). Aboriginal gangs: A report to the Correctional Service of Canada on Aboriginal youth gang members in federal corrections system. Ottawa, ON: Correctional Service Canada.

National Indian Brotherhood and Assembly of First Nations. (1989). Report of the national inquiry into First Nations child care. Ottawa, ON: Assembly of First Nations.

OECD Directorate of Education. (2004, August). OECD early childhood education and care policy: Canada country note. Human Resources and Social Development Canada. Retrieved January 28, 2009, from http://www.hrsdc.gc.ca/ en/cs/sp/sdc/socpol/publications/reports/2004-002619/ Country.pdf.

Polischuk, H. (2009, February 14). Expert suggest "social" solution. Leader Post, p. A3.

Preston, J. P. (2008a). Enhancing Aboriginal child wellness: The potential of early learning programs. First Nations Perspectives: The Journal of Manitoba First Nations, 1(1), 98-120.

Preston, J. P. (2008b). The urgency of postsecondary education for Aboriginal peoples [Electronic version]. Canadian Journal of Educational Administration and Policy, 86, 1-22.

Public Safety Canada. (2007). Youth gang in Canada: What do we know? Ottawa, ON: Author.

Royal Commission on Aboriginal People. (1996). Report of the Royal Commission on Aboriginal Peoples, Volume 3: Gathering strength. Ottawa, ON: Minister of Supply and Services Canada.

Saccone, J. (2005, April 23). Graffiti mars city neighbourhood. The StarPhoenix, p. A12.

Schneider, S. (2007). More support for PALS Program at Saint Mary's. Saint Mary's Times, 37(1), 1-2.

Sexton, T., \& Alexander, J. (2000, December). Functional Family Therapy. Juvenile Justice Bulletin, Washington, DC: Office of Juvenile Justice and Delinquency Prevention Care. Retrieved January 18, 2009, from http://www.ncjrs. gov/html/ojjdp/jjbul2000_12_4/contents.html.
Spergel, I., Chance, R., Ehrensaft, K., Regulus, T., Kane, C., Laseter, R., Alexander, A., et al. (1994). Gang suppression and intervention: Community models. Washington, DC: Office of Juvenile Justice and Delinquency Prevention. Retrieved July 20, 2009, from http://www.ncjrs.org/pdffiles/ gangcorr.pdf.

Stolte, E. (2008, March 25). Boom fuelling gang growth: Report; drug dealers heading west to cash in on economy. Edmonton Journal, p. B3.

Thornberry, T. P. (1998). Membership in youth gangs and involvement in serious violent offending. In R. Loeber and D. P. Farrington (Eds.), Serious and violent juvenile offenders: Risk factors and successful intervention (pp. 147-166), Thousand Oaks, CA: Sage.

Violato, C., Genuis, M., \& Oddone-Paolucci, E. (2008). Compendium 2000 on effective correctional programming: Chapter 11: Treatment and intervention approaches with families. Correctional Services Canada. Retrieved July 20, 2009, from http://www.csc-scc.gc.ca/text/rsrch/compendium/2000/chap 11-eng.shtml.

Warick, J. (2003, August 22). Aboriginal gangs an "epidemic." The StarPhoenix, p. A1.

Washington State Institute for Public Policy. (2004). Benefits and cost prevention of early intervention programs for youth. Olympia, WA: Author. Retrieved January 21, 2009, from http://www.wsipp.wa.gov/rptfiles/04-07-3901.pdf.

Washington State Institute for Public Policy. (2004). Benefits and cost prevention of early intervention programs for youth. Olympia, WA: Author. Retrieved July 21, 2008, from http://www.wsipp.wa.gov/rptfiles/04-07-3901.pdf.

Webster-Stratton, C. (2000, June). The Incredible Years training series. Juvenile Justice Bulletin, Washington, DC: Office of Juvenile Justice and Delinquency Prevention Care. Retrieved January 18, 2009, from http://www.ncjrs.gov/ html/ojjdp/2000_6_3/contents.html.

Wisconsin Center of Education Research. (2007). Families And Schools Together Project (FAST): Building relationships. Retrieved January 18, 2009, from http://www.wcer.wisc. edu/projects/projects.php?project_num $=64$. 